\title{
Pemanfaatan Air Limbah Wet Scrubber Flue Gas Desulphurization (FGD) Industri Kertas sebagai Medium Pertumbuhan Spirulina platensis
}

\author{
Isni Nur Khairunnissa ${ }^{1 *}$, Prima Besty Asthary ${ }^{2}$, Saepulloh $^{2}$, Rahmaniar Mulyani ${ }^{1}$ \\ ${ }^{1}$ Universitas Jenderal Achmad Yani, Jl. Terusan Jenderal Sudirman, Cimahi, Indonesia \\ ${ }^{2}$ Balai Besar Pulp dan Kertas, Jl. Raya Dayeuhkolot No. 132, Bandung, Indonesia
}

Diterima : 21 Juli 2018, Revisi akhir : 27 Desember 2018, Disetujui terbit : 27 Desember 2018

\section{Utilization of Wet Scrubber Wastewater from Flue Gas Desuphurization (FGD) of Paper Industry as a Growth Medium for Spirulina platensis}

\begin{abstract}
The flue gas desulohurization (FGD) withwet scrubber is a process to reduce the concentration of SOx of the flue gas from combustion. This process can resolve the air pollution by reducing gas emission and the dust particles in the liquid droplets to produce cleaner flue gas. The wet scrubber wastewater is acidic. An alternative utilization of wet scrubber wastewater is for cultivation of microalgae. Spirulina platensis is bluish-green microalgae containing high nutritional value. The objective of this research is to determine the potential and the optimum concentration of wastewater from wet scrubber as growth medium of Spirulina. platensis. The research method was observation in the laboratory with a completely randomized design (CRD) with 5 treatments and 5 repetitions. The wastewater from wet scrubber with a concentration of $0 \%, 25 \%, 50 \%, 75 \%$, and $100 \%$ was used as growth medium of S. platensis. During cultivation, $\mathrm{pH}$, biomass production, and pigment phycocyanin were measured. The results indicated that the wastewater of wet scrubber can be utilized as a growth medium of S. platensis. The optimum concentration for the growth of $S$. platensis is the mixture of $75 \%$ of the wastewater from wet scrubber and $25 \%$ of medium Zarrouk.
\end{abstract}

Keywords : wastewater, flue gas desulphurization, wet scrubber, Spirulina platensis

\begin{abstract}
Abstrak
Proses flue gas desulohurization (FGD) dengan wet scrubber adalah suatu proses untuk menurunkan konsentrasi $\mathrm{SO}_{x}$ gas buang hasil pembakaran. Proses inidapat mengatasi polusi udara dengan cara menurunkan emisi gas dan partikel debu sehingga menghasilkan gas buangan yang lebih bersih. Air limbah wet scrubber bersifat asam. Salah satu alternatif pemanfaatan air limbah wet scrubber adalah untuk budidaya mikroalga. Spirulina platensis merupakan mikroalga yang berwarna hijau kebiruan yang mempunyai nilai gizi tinggi. Penelitian ini bertujuan untuk mengetahui potensi air limbah wet scrubber sebagai medium pertumbuhan $S$. platensis dan untuk mengetahui konsentrasi air limbah yang optimum bagi pertumbuhan $S$. platensis. Metode yang digunakan adalah Rancangan Acak Lengkap (RAL) dengan 5 perlakuan dan 5 ulangan. Air limbah wet srubber dengan konsentrasi 0\%, 25\%, 50\%, 75\%, dan 100\% digunakan sebagai medium pertumbuhan S. platensis. Selama kultivasi, dilakukan pengamatan $\mathrm{pH}$, produksi biomassa, dan kandungan fikosianin. Hasil menunjukkan bahwa air limbah wet scrubber dapat dimanfaatkan sebagai medium pertumbuhan $S$. platensis. Konsentrasi optimum bagi pertumbuhan $S$. platensis adalah campuran dari 75\% air limbah wet scrubber dan 25\% medium Zarrouk.
\end{abstract}

Kata kunci : air limbah, flue gas desulphurization, wet scrubber, Spirulina platensis 


\section{Pendahuluan}

Perkembangan yang pesat saat ini, khususnya dalam bidang industri yang menggunakan bahan bakar fosil, menyebabkan udara di atmosfer yang kita hirup menjadi tercemar oleh gas-gas yang dihasilkan dari pembakaran. Komponen yang berpengaruh terhadap pencemaran udara, yaitu $\mathrm{CO}, \mathrm{CO}_{2}, \mathrm{NO}_{2}, \mathrm{SO}_{2}$, dan partikulat (Budiyono 2001; Setiawan, Surachman, Asthary, \& . (2014). Akibat yang ditimbulkan dari pencemaran udara ini sangat merugikan baik terhadap kesehatan manusia, maupun terhadap lingkungan. Contohnya antara lain meningkatnya kadar $\mathrm{CO}_{2}$ di atmosfir mengakibatkan kenaikan suhu bumi dan pemanasan global. Selain itu, peningkatan $\mathrm{NO}_{2}$ dan $\mathrm{SO}_{2}$ di atmosfer dapat mengakibatkan hujan asam (Budiyono, 2001; Erni \& Yatim, 2007).

Salah satu upaya yang dilakukan industri untuk mengendalikan pencemaran udara yang berbahaya ini adalah dengan menggunakan sistem Flue Gas Desulphurization (FGD) jenis wet scrubber. FGD adalah suatu carauntuk menurunkan konsentrasi $\mathrm{SO}_{\mathrm{x}}$ pada gas buang hasil pembakaran dengan caramengikat $\mathrm{SO}_{2}$ dalam gas buang di cerobong asap dengan absorben yang disebut scrubbing (Mayasari, 2013). Salah satu tipe FGD adalah sistem wet scrubber membuang partikel polutan dengan cara menangkapnya dalam tetesan atau butiran cairan sehingga dapat menghasilkan gas buang yang lebih bersih (Sunardi et al., 2013). Sistem wet scrubber memiliki efisiensi tinggi dan dapat menghasilkan produk gipsum dengan kualitas tinggi (Mayasari, 2013). Dalam sistem wet scrubber, kandungan SOx dan NOx dapat menyebabkan air limbah bersifat asam sehingga perlu dikelola dengan baik (Zakaria, 2018). Pengelolaan air limbah tersebut sebaiknya dilakukan dengan sistem tersendiri karena akan mengganggu kehidupan mikroorganisme dalam air (Kusnoputranto, 1985).

Salah satu alternatif pengelolaan air limbah tersebut adalah dengan memanfaatkannya untuk budidaya mikroalga karena kandungan zat organik dan anorganik di dalamnya (Hadiyanto \& Azim, 2012). Toleransi mikroalga terhadap gas-gas tersebut sangat bervariasi tergantung spesiesnya. Menurut Kumar, et al (2011) Spirulina platensis adalah salah satu mikroalga yang toleran terhadap gas $\mathrm{SO}_{\mathrm{x}}, \mathrm{NO}_{\mathrm{x}}$, dan gas $\mathrm{CO}_{2}$ dengan konsentrasi $<12 \%$. S. platensis mudah dibudidayakan karena memiliki tingkat reproduksi yang tinggi dan mudah beradaptasi pada berbagai lingkungan (Promya, et al., 2008). Di Indonesia, S. platensis dikembangkan dan diproduksi secara komersial sebagai suplemen makanan yang aman dikonsumsi oleh manusia (Soni, 2010). Selain mudah dicerna, mikroalga ini mengandung senyawa-senyawa yang diperlukan oleh tubuh, seperti protein, lipid, karbohidrat, asam lemak tidak jenuh, vitamin-vitamin, mineral, asam amino, dan beberapa jenis pigmen yang sangat bermanfaat.

Salah satukendalayang dihadapipadabudidaya S. platensis adalah biaya yang mahal untuk medium yang baik dan mendukung pertumbuhan S. platensis (Setyaningsih \& Saputra, 2011). Berdasarkan hal tersebut, penelitian ini bertujuan untuk mengetahui potensi air limbah proses FGD wet scrubber untuk kultivasi S. platensis sehingga dapat mengurangi beban Instalasi Pengolahan Air Limbah (IPAL) dalam mengolah air limbah tersebut dan mengurangi biaya media kultur $S$. platensis.

\section{Bahan dan Metode}

Penelitian ini dilakukan di Balai Besar Pulp dan Kertas, Bandung. Bibit mikroalga S. platensis diperoleh dari Pusat Penelitian Bioteknologi LIPI, Cibinong. Air limbah proses FGD sistem wet scrubber sebagai media pertumbuhan S. platensis diperoleh dari industri kertas dandikarakterisasi di Balai Besar Pulp dan Kertas dengan parameter yang disajikan pada Tabel 1.

S. platensis dipelihara dan diperbanyak dalam dalam medium Zarrouk dengan komposisi $\mathrm{NaHCO}_{3} 16,8 \mathrm{~g} / \mathrm{L}, \mathrm{NaNO}_{3} 2,5 \mathrm{~g} / \mathrm{L}, \mathrm{K}_{2} \mathrm{SO}_{4} 1 \mathrm{~g} / \mathrm{L}$, $\mathrm{NaCl} 1 \mathrm{~g} / \mathrm{L}, \mathrm{K}_{2} \mathrm{HPO}_{4}$ 0,5 g/L,Na EDTA $0,08 \mathrm{~g} / \mathrm{L}$, $\mathrm{CaCl}_{2} 0,04 \mathrm{~g} / \mathrm{L}, \mathrm{FeSO}_{4} .7 \mathrm{H}_{2} \mathrm{O} 0,01 \mathrm{~g} / \mathrm{L}, \mathrm{MgSO}_{4}$ $0,2 \mathrm{~g} / \mathrm{L}$ (Chang, Wu, Bian, Feng, \& Leung, 2013) serta diaerasi. Kultur $S$. platensis dibiakkan pada temperatur $30 \pm 1^{\circ}$ (Feng, Wu, \& Wang, 2007) dengan intensitas cahaya berkisar antara 15003000 lux (Mahmoud, Ibrahim, \& Ali, 2016; Uday Bhaskar, Gopalaswamy, \& Raghu, 2005)..

Kultur S. platensis ditambahkan ke dalam botol percobaan yang telah berisi medium pertumbuhan. Perbandingan kultur S. platensis dan medium Zarrouk adalah 1:4. Air limbah wet scrubber ditambahkan ke dalam campuran kultur S. platensis dan medium Zarrouk dengan variasi konsentrasi seperti pada Tabel 2. Kultur S. platensis yang digunakan memiliki $\mathrm{pH}$ awal sekitar 9. Kultivasi S. platensis dilakukan di 
Tabel 1. Parameter Uji Karakteristik Air Limbah Wet Scrubber

\begin{tabular}{ll}
\hline Parameter & \multicolumn{1}{c}{ Metode Uji } \\
\hline Total nitrogen & SNI 06-6989.52-2005 \\
Padatan tersuspensi & SNI 698.3-2004 \\
$\begin{array}{l}\text { Derajat keasaman (pH) } \\
\text { Biological Oxygen }\end{array}$ & SNI 06-6989.11-2004 \\
Demand (BOD) & SNI 6989.72-2009 \\
Chemical Oxygen & \\
$\begin{array}{l}\text { Demand }(\mathrm{COD}) \\
\text { Sulfat }\left(\mathrm{SO}_{4}^{2-}\right)\end{array}$ & SNI 6989.73-2009 \\
\hline
\end{tabular}

Tabel 2. Variasi Konsentrasi Medium Zarrouk dan Air Limbah Wet Scrubber

\begin{tabular}{lcc}
\hline \multirow{2}{*}{$\begin{array}{l}\text { Kode } \\
\text { Perlakuan }\end{array}$} & \multicolumn{2}{c}{ Komposisi $(\% \mathrm{v} / \mathrm{v})$} \\
\cline { 2 - 3 } & $\begin{array}{c}\text { Air Limbah Wet } \\
\text { Scrubber }\end{array}$ & $\begin{array}{c}\text { Medium } \\
\text { Zarrouk }\end{array}$ \\
\hline A & 0 & 100 \\
B & 25 & 75 \\
C & 50 & 50 \\
D & 75 & 25 \\
E & 100 & 0 \\
\hline
\end{tabular}

Laboratorium Toksikologi dengan pemberian cahaya dari lampu neon dengan intensitas cahaya 4000 lux. Pada variasi 0\% tanpa penambahan air limbah wet scrubber bertujuan untuk mengetahui pengaruh penambahan air limbah wet scrubber terhadap pertumbuhan $S$. platensis.

Percobaan ini dilakukan selama 9 hari dan pengamatan dilakukan setiap 24 jam sekali terhadap $\mathrm{pH}$, kerapatan optik, dan kandungan fikosianin mikroalga. Pengukuran nilai $\mathrm{pH}$ dilakukan dengan menggunakan alat $\mathrm{pH}$ meter, sedangkan nilai kerapatan optik diukur dengan menggunakan spektrofotometer pada panjang gelombang ( $\lambda$ ) $680 \mathrm{~nm}$ (Borowitzka, Michael, \& Lesly, 1988). Pengamatan uji fikosianin pada $S$. platensis dilakukan dengan metode beku-cair (freeze-thaw) secara berulang-ulang dan konsentrasi fikosianin ditentukan dengan menggunakan alat spektrofotometer. Sampel $S$. platensis dipisahkan biomassanya dengan cara sentrifugasi. Biomassa yang telah diperoleh kemudian ditambahkan dengan buffer fosfat pH 7 dan dibekukan pada suhu $0^{\circ} \mathrm{C}$ selama 24 jam. Setelah dibekukan, biomassa dengan filtrat dipisahkan kembali dengan cara sentrifugasi. Filtrat yang berwarna kebiruan dipisahkan dan diukur absorbansinya dengan spektrofotometer pada $\lambda 615 \mathrm{~nm}$ yang merupakan panjang gelombang maksimum $\left(\lambda_{\max }\right)$ untuk fikosianin dan pada $\lambda 652 \mathrm{~nm}$ yang merupakan panjang gelombang maksimum $\left(\lambda_{\text {max }}\right)$ untuk alkosianin. Untuk mendapatkan nilai fikosianin dilakukan perhitungan pada Persamaan (1) (Ajayan et al., 2012).

$(P C)=\frac{\{A 615-(0.474 \times A 652)\}}{5.34}$

dengan :

PC : Kadar fikosianin

A615 : Nilai absorbansi pada panjang gelombang $(\lambda) 615 \mathrm{~nm}$

A652 : Nilai absorbansi pada panjang gelombang $(\lambda) 652 \mathrm{~nm}$

Data biomassa dan kandungan fikosianin yang diperoleh selama penelitian dianalisis secara statistik dengan ANOVA, dilanjutkan dengan uji jarak Duncan dengan derajat kepercayaan 0,05 untuk mengetahui perbedaan di antara semua perlakuan.

\section{Hasil dan Pembahasan}

\section{Karakteristik Air Limbah Wet Scrubber}

Berdasarkan hasil pengamatan secara fisik terhadap air limbah wet scrubber terlihat bahwa air berwarna bening kecoklatan sehingga penetrasi cahaya masih memungkinkan terjadi dan proses fotosintesis pada $S$. platensis tidak akan terhambat (Sumiarsa, et.al., 2011). Menurut Fogg (1975), cahaya merupakan sumber energi yang diperlukan dalam proses fotosintesis, serta jumlah energi yang diterima bergantung pada kualitas, kuantitas, dan periode penyinaran. Hasil analisis karakteristik air limbah wet scrubber ditunjukkan pada Tabel 3. Hasil uji COD dan BOD menunjukan hasil yang cukup rendah dan $\mathrm{pH}$ air limbah wet scrubber bersifat asam. Mayasari (2013) menyatakan penyebab air limbah wet scrubber bersifat asam adalah hasil reaksi dari gas $\mathrm{SO}_{2}$ dalam gas buang dengan cairan penyerap yang membentuk $\mathrm{H}_{2} \mathrm{SO}_{4}$ yang terjadi di dalam seperti persamaan reaksi 1 dan 2 .

$$
\begin{aligned}
& \mathrm{SO}_{2}+\mathrm{H}_{2} \mathrm{O} \rightarrow \mathrm{H}^{+}+\mathrm{HSO}_{3}^{-} \\
& \mathrm{H}^{+}+\mathrm{HSO}_{3}^{-}+1 / 2 \mathrm{O} \rightarrow \mathrm{H}_{2} \mathrm{SO}_{4}
\end{aligned}
$$

Air limbah wet scrubber masih mengandung nitrogen $(\mathrm{N})$ walaupun rendah, yaitu sebesar 2,74 
Tabel 3. Karakteristik Air Limbah Wet Scrubber

\begin{tabular}{lcc}
\hline Parameter & Satuan & Hasil Uji \\
\hline Derajat keasaman $(\mathrm{pH})$ & - & 4,3 \\
Padatan tersuspensi & $\mathrm{mg} / \mathrm{L}$ & 43 \\
Total nitrogen & $\mathrm{mg} / \mathrm{L}$ & 2,74 \\
$\mathrm{BOD}$ & $\mathrm{mg} / \mathrm{L}$ & 14 \\
$\mathrm{COD}$ & $\mathrm{mg} / \mathrm{L}$ & 23 \\
Sulfat $\left(\mathrm{SO}_{4}{ }^{2-}\right)$ & $\mathrm{mg} / \mathrm{L}$ & 84,9 \\
\hline
\end{tabular}

$\mathrm{mg} / \mathrm{L}$. Nitrogen pada pertumbuhan S. platensis sangat diperlukan sebagai sintesis asam amino penyusun protein.

S. platensis dapat toleran terhadap gas $\mathrm{SO}_{\mathrm{x}}$, $\mathrm{NO}_{x}$ dan $\mathrm{CO}_{2}$ dengan konsentrasi $<12 \%$ (Kumar et al., 2011). Sementara itu, air limbah yang digunakan pada percobaan ini mengandung $\mathrm{SO}_{x}$ yang rendah, yaitu sebesar $84,9 \mathrm{mg} / \mathrm{L}$ setara dengan $0,00849 \%$ (kurang dari 12\%) sehingga S. platensis dapat tumbuh baik dan kurang berpengaruh pada penurunan $\mathrm{pH}$ yang drastis. Matsumoto, et.al (1997) menyatakan bahwa ketika konsentrasi $\mathrm{SO}_{2}$ mencapai 400 ppm, maka $\mathrm{pH}$ media dapat menjadi lebih rendah dari 4 setelah beberapa hari sehingga akan mempengaruhi produktivitas mikroalga.

\section{Pengaruh Variasi Penambahan Air Limbah Wet Scrubber Terhadap Pertumbuhan Spirulina platensis}

Pada penelitian ini dilakukan pengamatan terhadap nilai derajat keasaman $(\mathrm{pH})$ untuk mengetahui pengaruh penambahan air limbah wet scrubber sebagai medium $S$. platensis terhadap pH S. platensis. Suminto (2009) mengatakan bahwa pengontrolan $\mathrm{pH}$ medium sangat penting untuk menjaga keseimbangan $S$. platensis. Menurut Habib, et al (2008), nilai pH yang baik bagi S. platensis pada kisaran 8,3-11. Gambar 1 menunjukkan bahwa pada semua perlakuan memiliki nilai $\mathrm{pH}$ berkisar antara 8.9-10,7 yang masih dalam kisaran normal untuk pertumbuhan S. platensis.

Berdasarkan Gambar 1, pada hari ke-2 hingga hari ke-8 kultur $S$. platensis pada semua perlakuan cenderung mengalami peningkatan nilai $\mathrm{pH}$ kecuali pada perlakuan E (air limbah wet scrubber 100\%). Kenaikan nilai $\mathrm{pH}$ pada suatu media kultur berbanding lurus dengan penambahan bikarbonat yang dapat menghasilkan karbon dioksida untuk digunakan dalam proses fotosintesis (Borowitzka et al., 1988). Suantika \& Hendrawandi (2009) menyatakan bahwa reaksi yang terjadi ketika $\mathrm{CO}_{2}$ bereaksi dengan air adalah terbentuknya asam karbonat $\left(\mathrm{H}_{2} \mathrm{CO}_{3}\right)$ yang akan berdisosiasi menjadi karbonat $\left(\mathrm{CO}_{3}{ }^{2-}\right)$ dan ion bikarbonat $\left(\mathrm{HCO}_{3}^{-}\right)$. Proses pembentukan karbon dioksida $\left(\mathrm{CO}_{2}\right)$ dari bikarbonat itu terjadi ketika asimilasi pada gas $\mathrm{CO}_{2}$ reaksi akan bergeser kearah kanan, karena $\mathrm{HCO}_{3}^{-}$akan berubah menjadi $\mathrm{CO}_{2} . \mathrm{CO}_{2}$ yang terbentuk akan menggantikan $\mathrm{CO}_{2}$ bebas yang telah diserap oleh $S$. platensis (Persamaan 4).

$$
\mathrm{HCO}_{3}^{-} \leftrightarrow \mathrm{CO}_{2}+\left(\mathrm{H}_{2} \mathrm{CO}_{3}\right) \leftrightarrow \mathrm{CO}_{3}^{2-}
$$

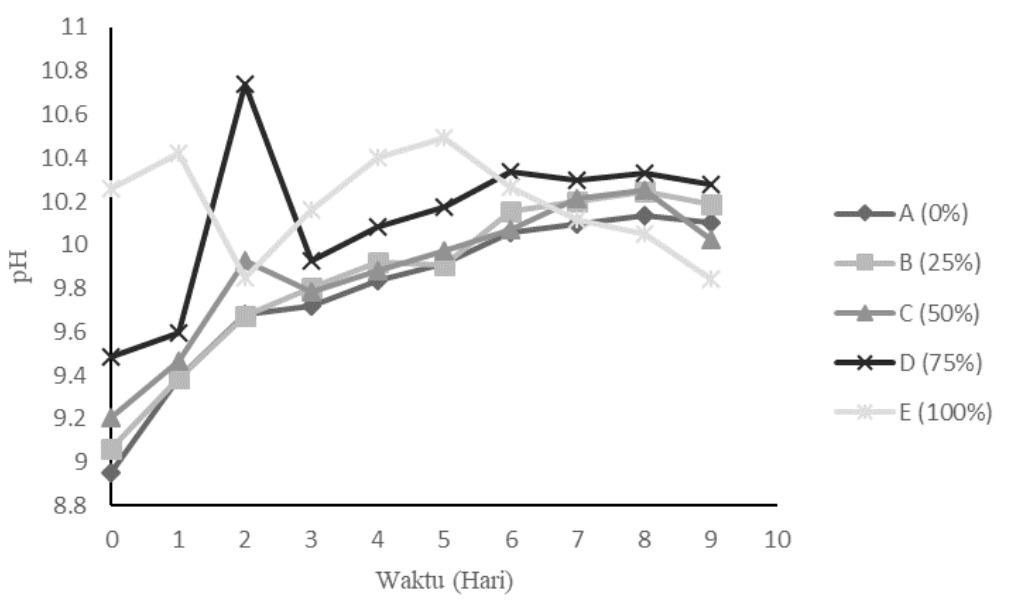

Gambar 1. pH Pertumbuhan Spirulina platensis 


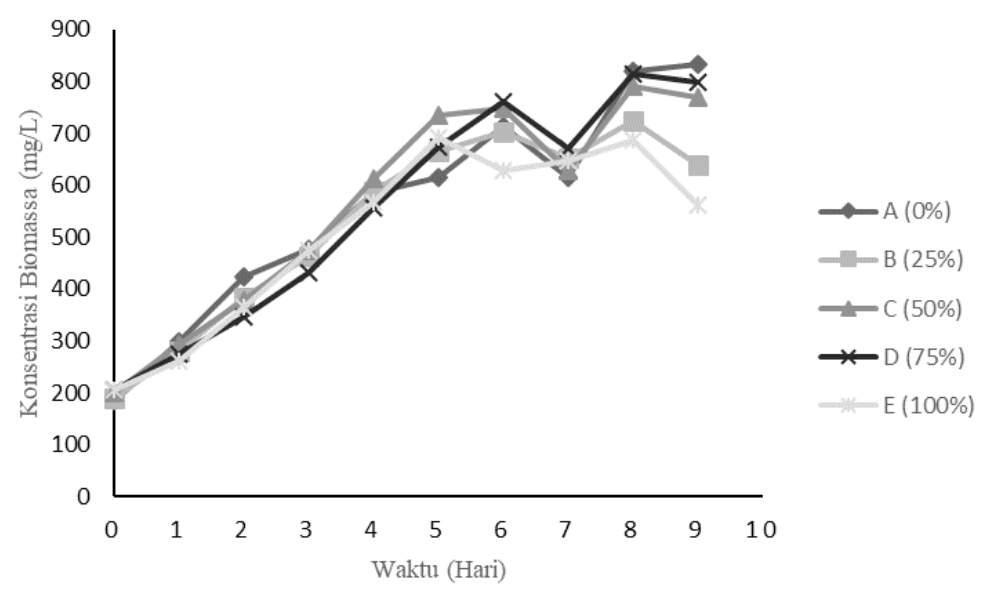

Gambar 2. Biomassa Sprirulina platensis

Penurunan $\mathrm{pH}$ terjadi pada hari ke-9 pada semua perlakuan, namun pada perlakuan $\mathrm{E}$ terjadi pada hari ke-6. Hal ini dikarenakan pada perlakuan E media yang digunakan adalah hanya air limbah wet scrubber $100 \%$ sehingga ketersediaan nutrisi pada medium tersebut lebih sedikit dibandingkan dengan perlakuan lainnya yang masih mengandung medium Zarrouk. Selanjutnya, laju pertumbuhan $S$. platensis pada perlakuan E akan cepat mengalami penurunan.

Biomassa $S$. platensis pada medium air limbah wet scrubber dengan konsentrasi $0 \%, 25 \%, 50 \%, 75 \%$, dan $100 \%$ disajikan pada Gambar 2. Dapat terlihat bahwa terjadi pertumbuhan $S$. platensis yang ditandai dengan peningkatan biomassa hingga hari ke-7. Pada fase lag diduga terjadi begitu singkat sehingga tidak dapat digambarkan. Selanjutnya, pada hari ke-7 terlihat bahwa pertumbuhan S. platensis mengalami penurunan biomassa dan mengalami kenaikan kembali dan mengalami keadaan puncak atau sel memasuki fase eksponensial pada hari ke-8. Pada fase ini, pertumbuhan dan aktivitas sel dalam keadaan maksimum yaitu sel terus bereproduksi yang didukung oleh nutrien, $\mathrm{pH}$, dan intensitas cahaya pada medium yang masih dapat memenuhi kebutuhan fisiologis S. platensis. Hal ini diperkirakan masih ada nutrisi yang tersimpan pada medium sehingga $S$. platensis mampu hidup kembali. Kultur $S$. platensis mengalami penurunan jumlah biomassa dan memasuki fase kematian pada hari ke-9. Penurunan jumlah biomassa sel dapat diakibatkan oleh ketersediaan nutrisi yang semakin menipis dan akumulasi metabolit $\left(\mathrm{NO}_{2}^{-}\right.$dan $\left.\mathrm{NH}_{4}^{+}\right)$ yang menghambat pertumbuhan $S$. platensis
(Suantika \& Hendrawandi, 2009). Lavens \& Sorgeloos (1996) menyatakan bahwa kematian sel dapat disebabkan oleh mulai berkurangnya nutrien yang tersedia sehingga tidak mampu mendukung pertumbuhan sel. Akibatnya, laju kematian sel lebih besar dibandingkan dengan laju pertambahan sel.

Hasil yang diperoleh selama penelitian dianalisis dengan menggunakan uji analisis varian (ANOVA). Data harian diperoleh selama penelitian pengaruh air limbah proses FGD sistem wet scrubber terhadap pertumbuhan biomassa yang diperoleh dengan menggunakan analisis varian (ANOVA). Hasil analisis uji ANOVA yang disajikan pada Tabel 4 menunjukan hasil $\mathrm{p}>0,05$ yang berarti biomassa tidak berpengaruh secara nyata terhadap pertumbuhan $S$. platensis yang dikultur menggunakan air limbah proses FGD sistem wet srubber ini.

Pada kelima variasi konsentrasi biomassa yang dihasilkan mencapai titik puncak, yaitu pada hari ke- 8 dengan biomassa tertinggi pada perlakuan A sebanyak $819,41 \mathrm{mg} / \mathrm{L}$ sedangkan biomassa terendah diperoleh pada perlakuan $\mathrm{E}$ sebanyak 687,96 mg/L. Hasil biomassa dalam percobaan cukup tinggi dibandingkan dengan penelitian Asthary (2013) dengan penambahan medium dari efluen industri kertas memperoleh biomassa tertinggi sebesar $395 \mathrm{mg} / \mathrm{L}$. Hasil analisis statistika data biomassa pada hari ke-8 pada Tabel 4 menunjukkan bahwa biomassa yang dihasilkan pada perlakuan B, C, dan D tidak berbeda nyata dengan biomassa pada perlakuan A (kontrol), dimana perlakuan D memiliki nilai biomassa paling mendekati perlakuan A.Sementara itu, biomassa perlakuan E berbeda 
Tabel 4. Konsentrasi Biomassa Spirulina platensis

\begin{tabular}{|c|c|c|c|c|c|c|c|c|c|c|}
\hline \multirow{3}{*}{ Perlakuan } & \multicolumn{10}{|c|}{ Konsentrasi Biomassa Spirulina platensis (mg/L) } \\
\hline & \multicolumn{10}{|c|}{ Hari ke- } \\
\hline & 0 & 1 & 2 & 3 & 4 & 5 & 6 & 7 & 8 & 9 \\
\hline $\mathrm{A}(0 \%)$ & $184.59^{\mathrm{a}}$ & $299.75^{\mathrm{b}}$ & $422.55^{b}$ & $476.26^{\mathrm{a}}$ & $585.59^{\mathrm{a}}$ & $615.18^{\mathrm{a}}$ & $713.91^{\mathrm{ab}}$ & $614.14^{\mathrm{a}}$ & $819.41^{b}$ & $833.97^{\mathrm{a}}$ \\
\hline $\mathrm{B}(25 \%)$ & $190.85^{\mathrm{ab}}$ & $279.63^{\mathrm{ab}}$ & $383.35^{\mathrm{ab}}$ & $464.05^{\mathrm{a}}$ & $587.76^{\mathrm{a}}$ & $665.24^{\mathrm{a}}$ & $703.22^{\mathrm{ab}}$ & $652.64^{\mathrm{a}}$ & $725.55^{\mathrm{ab}}$ & $639.57^{\mathrm{a}}$ \\
\hline $\mathrm{C}(50 \%)$ & $201.06^{\mathrm{ab}}$ & $292.92^{\mathrm{ab}}$ & $377.62^{\mathrm{ab}}$ & $474.69^{\mathrm{a}}$ & $612.05^{\mathrm{a}}$ & $734.33^{\mathrm{a}}$ & $748.41^{\mathrm{b}}$ & $628.00^{\mathrm{a}}$ & $791.12^{\mathrm{ab}}$ & $769.27^{\mathrm{a}}$ \\
\hline D (75\%) & $206.67^{b}$ & $274.15^{\mathrm{ab}}$ & $345.85^{\mathrm{a}}$ & $433.06^{\mathrm{a}}$ & $557.04^{\mathrm{a}}$ & $674.97^{\mathrm{a}}$ & $762.01^{\mathrm{b}}$ & $670.84^{a}$ & $813.46^{\mathrm{b}}$ & $799.16^{\mathrm{a}}$ \\
\hline E (100\%) & $205.62^{\mathrm{b}}$ & $260.81^{\mathrm{a}}$ & $365.27^{\mathrm{ab}}$ & $473.17^{\mathrm{a}}$ & $567.55^{\mathrm{a}}$ & $692.92^{\mathrm{a}}$ & $628.82^{\mathrm{a}}$ & $647.29^{\mathrm{a}}$ & $687.96^{\mathrm{a}}$ & $563.03^{\mathrm{a}}$ \\
\hline
\end{tabular}

Keterangan : Huruf yang berbeda setiap kolomnya menyatakan berbeda nyata $(p<0,05)$

nyata dengan biomassa perlakuan A di mana nilai rata-rata konsentrasi biomassa perlakuan $\mathrm{E}$ lebih rendah daripada biomassa perlakuan A. Halhal tersebut dapat diartikan bahwa penambahan air limbah wet scrubber hingga $75 \% \mathrm{v} / \mathrm{v}$ tidak menunjukkan efek negatif terhadap pertumbuhan S. platensis, sedangkan pengunaan air limbah wet scrubber $100 \%$ dapat menurunkan konsentrasi biomassa $S$. platensis.

Fikosianin merupakan pigmen yang penting dari mikroalga $S$. platensis dan merupakan protein kompleks yang mengandung lebih dari 20\% dari seluruh berat keringnya. Kandungan fikosianin dalam $S$. platensis dapat juga berpengaruh terhadap kualitas $S$. platensis. Kandungan fikosianin pada $S$. platensis selama percobaan disajikan pada Gambar 3. Konsentrasi pigmen fikosianin mengalami pola kenaikan konsentrasi biomassa fikosianin antara konsentrasi A (0\%), B (25\%), C (50\%), dan E (100\%) memiliki konsentrasi yang cenderung hampir sama kecuali pada konsentrasi D konsentrasi fikosianin mengalami kenaikan yang cukup drastis pada hari ke-8. Hal ini diperkirakan dipengaruhi oleh ketersediaan nutrisi yang terkandung dalam medium pertumbuhan $S$. platensis. Faktor yang mempengaruhi kandungan fikosianin, yaitu kandungan nitrogen dan cahaya. Menurut hasil penelitian Eriksen (2008), kandungan fikosianin dipengaruhi oleh konsentrasi sumber nitrogen yang tersedia pada kultur dimana kandungan fikosianin yang maksimum terdapat pada saat kandungan nitrogen dalam media kultur hampir habis dan turun secara drastis setelah sumber nitrogen tidak ada lagi pada media kultur. Hal ini disebabkan fikosianin memiliki peran dalam pembentukan nitrogen pada saat medium kultur kekurangan nitrogen fikosianin akan terdegradasi dan mejadi sumber nitrogen bagi kultur $S$. platensis (Boussiba \& Richmond, 1980). Pada hari ke-8, kandungan pigmen fikosianin tertinggi pada perlakuan D sebanyak 0,3760 $\mathrm{mg} / \mathrm{L}$ sedangkan kandungan pigmen

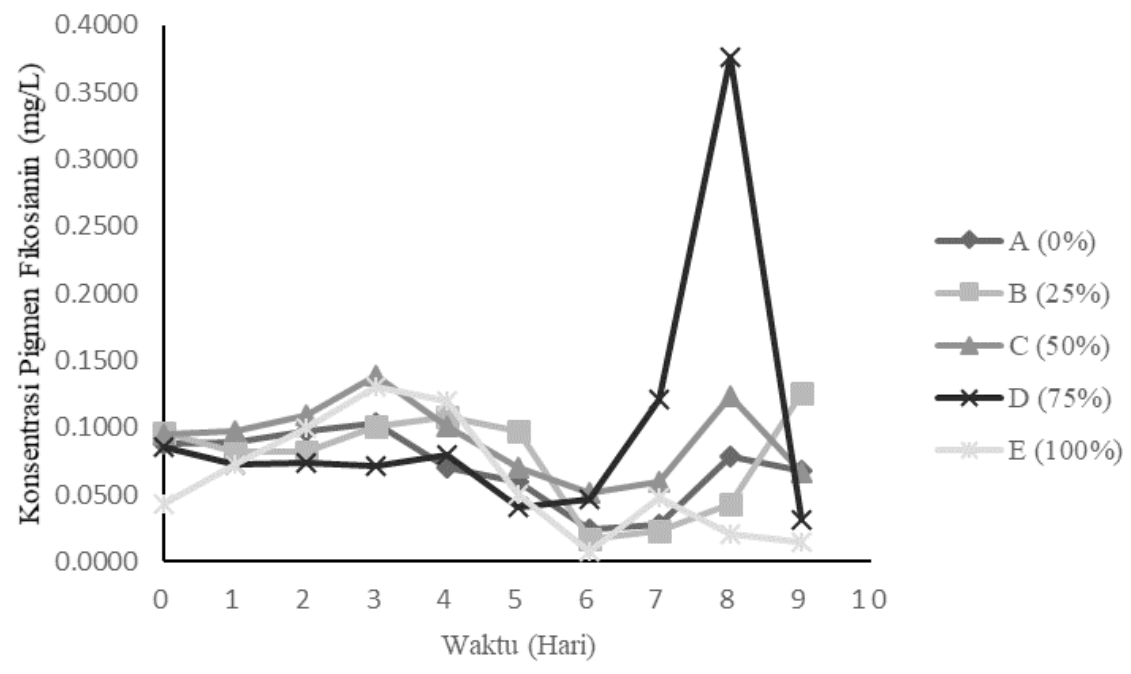

Gambar 3. Kandungan Fikosianin Spirulina platensis 


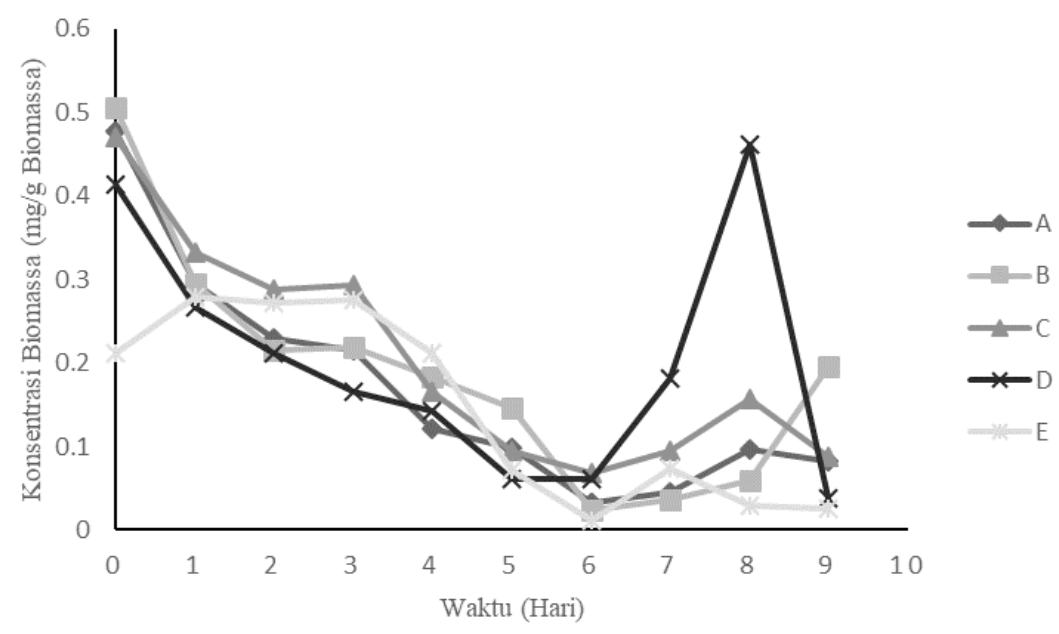

Gambar 4. Kandungan Fikosianin per gram Biomassa Spirulina platensis

fikosianin terendah pada perlakuan E sebanyak 0,0206 mg/L. Penurunan kandungan fikosianin pada $S$. platensis terjadi karena kandungan fikosianin per satuan massa semakin berkurang seperti yang ditunjukkan pada Gambar 4 .

Penurunan kandungan fikosianin pada kultur S. platensis ini dapat menjadi salah satu indikator penurunan kualitas $S$. platensis sehingga dapat dijadikan dasar penentuan waktu panen $S$. platensis. Kandungan fikosianin menurun pada hari ke-... Sehingga waktu panen ditentukan pada hari ke-8. Hasil analisis varian (ANOVA) dan uji jarak Duncan tehadap kandungan pigmen fikosianin S. platensis pada hari ke-8 yang dikultur menggunakan air limbah wet scrubber FGD ditampilkan pada Tabel 5. Hasil menunjukkan bahwa variasi penambahan air limbah memberikan pengaruh yang signifikan $(\mathrm{p}<0,05)$ terhadap kandungan fikosianin. Penambahan air limbah wet scrubber $75 \% \mathrm{v} / \mathrm{v}$ (perlakuan D) menunjukkan perbedaan yang signifikan

Tabel 5. Kandungan Fikosianin Spirulina platensis Pada Hari ke-8

\begin{tabular}{lc}
\hline Perlakuan & Kandungan Fikosianin $(\mathrm{mg} / \mathrm{L})$ \\
\hline A $(0 \%)$ & $0.0534^{\mathrm{a}}$ \\
$\mathrm{B}(25 \%)$ & $0.0263^{\mathrm{a}}$ \\
$\mathrm{C}(50 \%)$ & $0.0895^{\mathrm{a}}$ \\
$\mathrm{D}(75 \%)$ & $0.2885^{\mathrm{b}}$ \\
$\mathrm{E}(100 \%)$ & $0.0152^{\mathrm{a}}$ \\
\hline Keterangan : Huruf yang berbeda menyatakan berbeda nyata $(\mathrm{p}<0,05)$
\end{tabular}

dibandingkan dengan perlakuan lain. Oleh karena itu, perlakuan ini merupakan konsentrasi terbaik untuk meningkatkan kandungan pigmen fikosianin S.platensis.

\section{Kesimpulan}

Air limbah proses FGD sistem wet scrubber ini berpotensi sebagai medium pertumbuhan $S$. platensis. Media yang optimum bagi pertumbuhan S. platensis adalah campuran $75 \%$ air limbah wet scrubber proses FGD dan 25\% medium Zarrouk dengan biomassa yang dihasilkan sebesar 813,46 $\mathrm{mg} / \mathrm{L}$ pada hari ke-8. Hasil ini tidak berbeda nyata dengan biomassa kultur S.platensis menggunakan medium Zarrouk 100\% (kontrol), yaitu sebesar $819,41 \mathrm{mg} / \mathrm{L}$.

\section{Ucapan Terima Kasih}

Penulis mengucapkan terima kasih yang sebesar-besarnya terhadap seluruh karyawan Balai Besar Pulp dan Kertas khususnya bidang Sarana Riset dan Standardisasi atas kerjasama dan bantuannya dalam penyusunan materi ini.

\section{Daftar Pustaka}

Ajayan,K.V,Selvaraju,M.,\&Thirugnanamoorthy, K. (2012). Enrichment of chlorophyll and phycobiliproteins in Spirulina platensis by the use of reflector light and nitrogen sources : An in-vitro study. Biomass and Bioenergy, 47, 436-441. https://doi.org/10.1016/j. biombioe.2012.09.012 
Asthary, P. B., Setiawan, Y., Surachman, A., \& Perindustrian, K. (2013). Pertumbuhan Mikroalga Spirulina platensis dalam Efluen Industri Kertas. Jurnal Selulosa, 3(2), 97102.

Borowitzka, Michael, A., \& Lesly, B. J. (1988). Micro-algal Biotechnology. Cambridge University Press.

Boussiba, S., \& Richmond, A. E. (1980). C-Phycocyanin as a Storage Protein in the Blue-Green Alga Spirulina platensis Samy. Archives of Microbiology, 147, 143-147.

Budiyono, A. (2001). Pencemaran Udara: Dampak Pencemaran Udara Pada Lingkungan. Dirgantara, 2(1), 21-27. https://doi.org/10.1038/srep02598

Chang, Y., Wu, Z., Bian, L., Feng, D., \& Leung, D. Y. C. (2013). Cultivation of Spirulina platensis for biomass production and nutrient removal from synthetic human urine. Applied Energy, 102, 427-431. https://doi.org/10.1016/j. apenergy.2012.07.024

Eriksen, N. T. (2008). Production of phycocyanin - a pigment with applications in biology, biotechnology, foods and medicine. Microbiol Bioetechnol, 80(1), 1-14. https://doi.org/10.1007/s00253-0081542-y

Erni, \& Yatim, M. (2007). Dampak dan Pengendalian Hujan Asam. Jurnal Kesehatan Masyarakat, II(1), 146-151.

Feng, D., Wu, Z., \& Wang, D. (2007). Effects of $\mathrm{N}$ source and nitrification pretreatment on growth of Arthrospira platensis in human urine. Journal of Zhejiang UniversitySCIENCE A, 8(11), 1846-1852. https://doi. org/10.1631/jzus.2007.A1846

Fogg,G..(1975).Algalcultures and phytoplankton ecology. University of Wisconsin Press.

Habib, B., Parvin, M., Huntington, T. C., \& Hasan, M. R. (2008). A Review on Culture, Production, and Use of Spirulina platensis as Food for Humans and Feeds for Domestic Animal and Fish. FAO Fisheries and Aquaculture Circular No. 1034.

Hadiyanto, \& Azim, M. (2012). Mikroalga Sumber Pangan \& Energi Masa Depan. Semarang: UPT UNDIP Press.

Kumar, K., Dasgupta, C. N., Nayak, B., Lindblad, P., \& Das, D. (2011). Development of suitable photobioreactors for $\mathrm{CO} 2$ sequestration addressing global warming using green algae and cyanobacteria. Bioresource Technology, 102(8), 4945-4953. https://doi. org/10.1016/j.biortech.2011.01.054

Kusnoputranto, H. (1985). Kesehatan Lingkungan. Jakarta: Universitas Indonesia.
Lavens, P., \& Sorgeloos, P. (1996). Manual on the production and use of live food for aquaculture.

Mahmoud, R., Ibrahim, M., \& Ali, G. (2016). Closed photobioreactor for microalgae biomass production under indoor growth conditions, 7(1), 86-92.

Matsumoto, H., Hamasaki, A., Sioji, N., \& Ikuta, Y. (1997). Influence of CO2, SO2, and NO in Flue Gas on Microalgae Productivity. Journal of Chemical Engineering of Japan, $30(4), 620-624$.

Mayasari, F. (2013). Analisis Perhitungan Eksternalitas pada PLTU Muara Karang dengan Penggunaan Flue Gas Desulphurization. Jurnal Ristek, 2(1), 38-42.

Promya, J., Traichaiyaporn, S., \& Deming, R. (2008). Phytoremediation of kitchen wastewater by Spirulina platensis (Nordstedt) Geiteler: pigment content, production variable cost and nutritional value. Journal of Science and Technology and Nutritional Value, 2(3), 159-171.

Setiawan, Y., Surachman, A., Asthary, P. B., \& Saepulloh, S. (2014). Pemanfaatan emisi gas CO2 untuk budidaya Spirulina platensis dalam upaya penurunan Gas Rumah Kaca (GRK). Journal of Industrial Research (Jurnal Riset Industri), 8(2).

Setyaningsih, I., \& Saputra, A. T. (2011). Chemical Composition and Pigment Content of Spirulina fusiformis on the Different Harvesting Age in Fertilized Media. Jurnal Pengolahan Hasil Perikanan Indonesia, XIV(1), 63-69.

Soni, A. F. N. (2010). Budidaya Masal Spirulina platensis di Perairan Laut Jepara. Prosising Simposium Nasional Bioteknologi, Bogor: Dep.

Suantika, G., \& Hendrawandi. (2009). Efektivitas Teknik Kultur menggunakan Sistem Kultur Statis, Semi-kontinyu, dan Kontinyu terhadap Produktivitas dan Kualitas Kultur Spirulina sp. Matematika Dan Sains, 14(2), 41-50.

Sumiarsa, D., Jatnika, R., Kurnani, T. B. A., \& Lewaro, M. W. (2011). Perbaikan Kualitas Limbah Cair Peternakan Sapi perah. Akuatika, II(September), 93.

Suminto. (2009). Penggunaan Jenis Media Kultur Teknis terhadap Produksi dan Kandungan Nutrisi Sel Spirulina platensis. Jurnal Saintek Perikanan, 4(2), 53-61.

Sunardi, A. F., Ir, D., Dhofir, M., Soemarwanto, I., Elektro, T., Elektro, T., ... Udara, A. P. P. (2013). Perancangan dan Pembuatan Model Miniatur. Jurnal Mahasiswa TEUB, 1(1), $1-6$. 
Uday Bhaskar, S., Gopalaswamy, G., \& Raghu, R. (2005). A simple method for efficient extraction and purification of C-phycocyanin from Spirulina platensis Geitler. Indian Journal of Experimental Biology, 43(3), 277-279. https://doi. org/10.1023/A:1008914405302
Zakaria, T. (2018). Penerapan Flue Gas Dual Treatment pada Emisi Gas Buang Ketel Uap Bubling Fluideized Bed Boiler di PT. DDD. InTent, 1(1), 13-23. 
Lurnal Selulosa, Vol. 8, No. 2, Desember 2018: 95 - 104

- Halaman ini sengaja dikosongkan - 